\title{
Economics of Biodiesel Production in the Context of Fulfilling 20\% Blending with Petro-Diesel in Nepal
}

\author{
Ranjan Parajuli \\ Department of Development and Planning, Aalborg University, Denmark \\ Corresponding Email: parajuliranjan@gmail.com
}

\begin{abstract}
The article has attempted to introduce Jatropha curcas as one of the energy resource for partially substituting Petro-diesel in Nepal and is prepared to provide preliminary insight on the economics of biodiesel production in the country. There have been increasing trend of automobiles in the last two decades, which has also increased the total import volume of Petro-diesel in Nepal. The dependency on imported Petrodiesel and its escalating price is adversely affecting the national economy. To fulfill the $20 \%$ blending requirement of the Petro-diesel consumed in 2011 in the country, $4 \%$ of the uncultivated land of the country (representing terrain and hills only) are sufficient. With this realization, this article is prepared by the development of different scenarios in regard to substitution of $20 \%$ Petro-diesel in the country. The Scenarios basically comprise of price of seedlings required for cultivation, different yield of Jatropha plant, and the price of raw oil seeds required for processing. Prognosis of Petro-diesel consumption in the next 20 years is carried out considering the average growth rate of its sales in the last decade in the country, and further required volume of biodiesel required for blending is estimated. Techno-economic analysis carried out in this article has revealed that biodiesel can be economically produced with input parameters (plant yield greater than $2 \mathrm{~kg} /$ plant and with the price of oil seeds lower than $0.22 \mathrm{USD} / \mathrm{kg}$ ). The return on the investment in the bio diesel production and its utilization is also positive with these input parameters. The study estimated that production of biodiesel in the present context of increasing fuel prices and depleting resources, is an economically viable option, however, there is need of strong policy to entertain potential entrepreneurs and farmers for generating resource required for the partial substitution and also to look after the issues of food insecurity during the process of generating this resource.
\end{abstract}

Keywords: plantation, Jatropha curcas, yield, biodiesel, economics of production, Petro-diesel, substitution

\section{Background}

Nepal is a country endowed with natural resources over its entire area of 14.7 million hectares (ha). Country's topography is constituted with mountains (27\%), hills (56\%) and Terai (17\%) of the total land area are the major source of biodiversity [25]. The country has a population of 29.33 million and GDP of 7.65 (billion 2000 USD). The total energy production of the country is 8.82 (mil toe) and per capita electricity consumption of the Country is $91 \mathrm{kWh}$ (IEA, 2012). Of the total primary energy consumption reported for 2008/09 (400 PJ), share of traditional energy sources is $87 \%$ and shares of commercial and renewable sources are respectively $12 \%$ and less than $1 \%$ [25]. High speed diesel (HSD) has the largest stake of the commercial energy, which is $36 \%$, providing 18 PJ [25]. Since fossil fuels are the imported source of energy, there have been serious implication on the balance of trade, where the country is spending an enormous amount of its foreign currency to import fossil fuel. In the fiscal year 2011, country's imported petroleum products worth NRs 59.53 billion in the first 10 months, whereas the total export 
stood at NRs 52.67 billion, making the earning through total export less than the value of import of petroleum products [4].

Government of Nepal has been found initiating different pilot projects to produce biodiesel from Jatropha seed. Alternative Energy Promotion Centre (AEPC), a semi government wing of the Government of Nepal is also supporting in the pilot project of Jatropha plantation and processing of Jatropha seeds [1], which includes; district level awareness and capacity development for the promotion of Jatropha curcas. Additionally, it has supported local users group in different districts of the country for the commercial plantation of Jatropha and has also been involved in the preparation of guidelines for effective implementation of biofuel projects in the country [1]. In order to analyze, improve and control the quality of biodiesel being produced in the country, AEPC plans to work with the Nepal Oil Corporation, the Nepal Bureau of Standards Management, the Renewable Energy Testing Station and other organizations in the setting up of a laboratory [2]. Figure 1 indicates the districts of the country, which have supports for Jatropha cultivation from the government of Nepal.

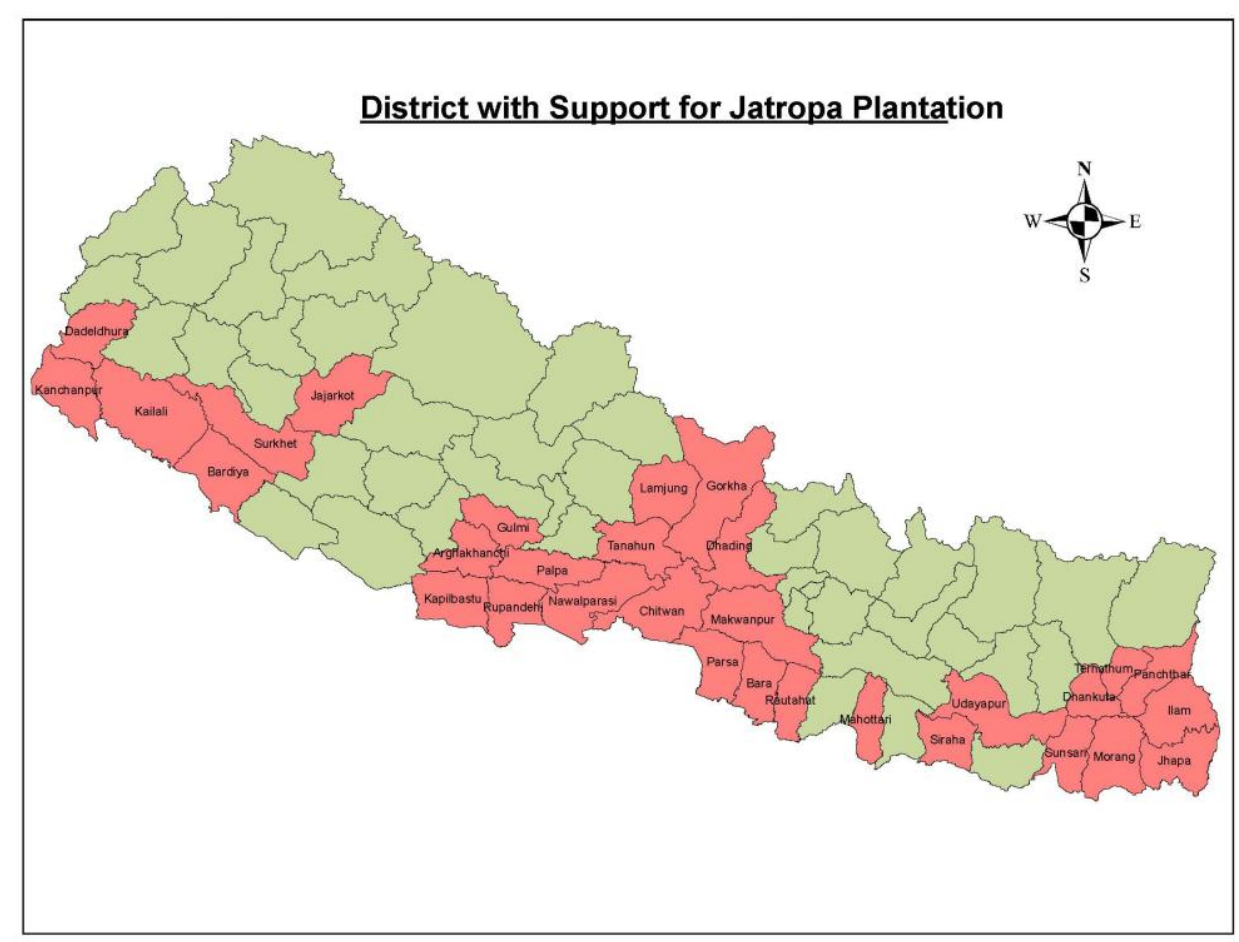

Figure 1: Government Support districts for Jatropha plantation [1]

Similarly, National Agricultural \& Environmental Forum (NAEF) are attempting to make biodiesel available even when there is no Jatropha available yet in sufficient quantity in Nepal by using another type of oil seeds and used oil. NAEF is involved in buying oil seeds from individuals who collect in small quantities from planted or wild plants, which is carried out to attract farmers and communities to promote cultivation of oil seed plant such as Jatropha, castor and others [16]. However, till date there is no any commercial production of biodiesel in the country. 


\section{Fossil Fuel Dependency in Nepal}

There has been an unprecedented growth rate of privately owned small and large motor vehicles as well as an unmonitored influx of mini-vans and buses used for mass transit during the last decade in Nepal, which have steadily accelerated the country's demand for fossil fuel particularly Petro-diesel (high speed diesel-HSD) (Figure 2) [17]. When we look on the sales volume of Petro-diesel in the country, the average growth rate on the sales is $7 \%$. The high inclination in the demand of Petro-diesel from 2008 has been realised in two aspects, firstly as discussed above due to increment in the number of vehicles and also because of consumer started storing Petro-diesel at different capacities, for not getting trouble due to fuel shortages, which have been very regular in the country from the last decades. Nepal Oil Corporation (NOC) has also been consistently unable to clear their dues with the Indian Oil corporation, largely because of their monthly losses which run up to millions [17].

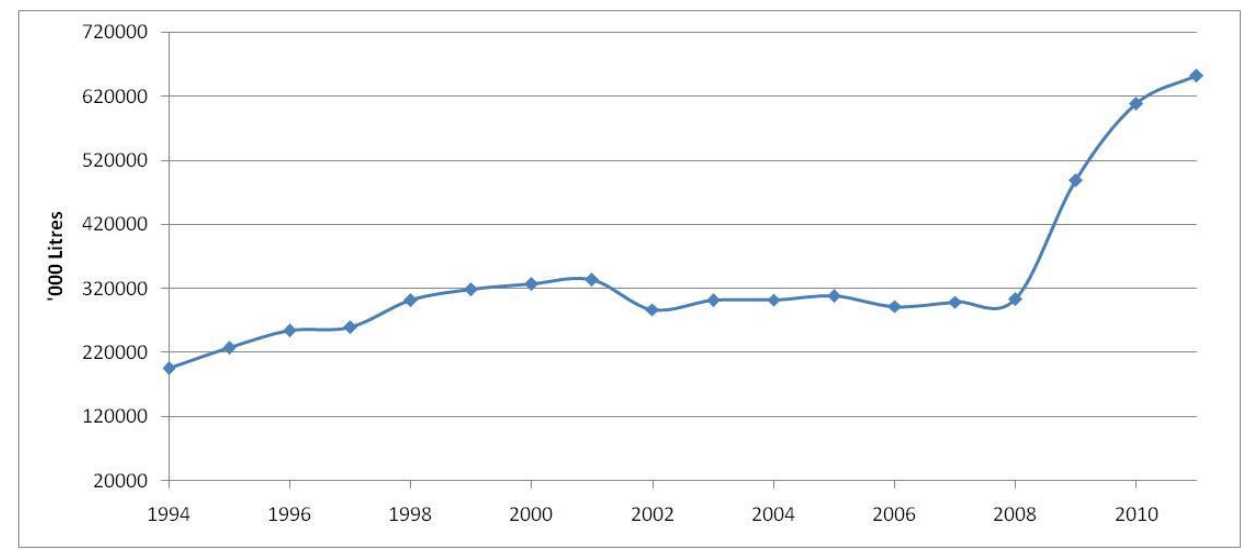

Figure 2: Sales volume of Petro-diesel in Nepal [17]

There has been an abrupt increment in the sales price of Petro-diesel in the country from the year 2000. Prices of Petro-diesel shown in Figure 3, is derived from [17] and calculated with the current currency conversion factor ( $1 \mathrm{USD}=89.17 \mathrm{NRs}$.). The average inflation of the diesel price is $9.15 \%$ (estimated for the period of 2000-2010).

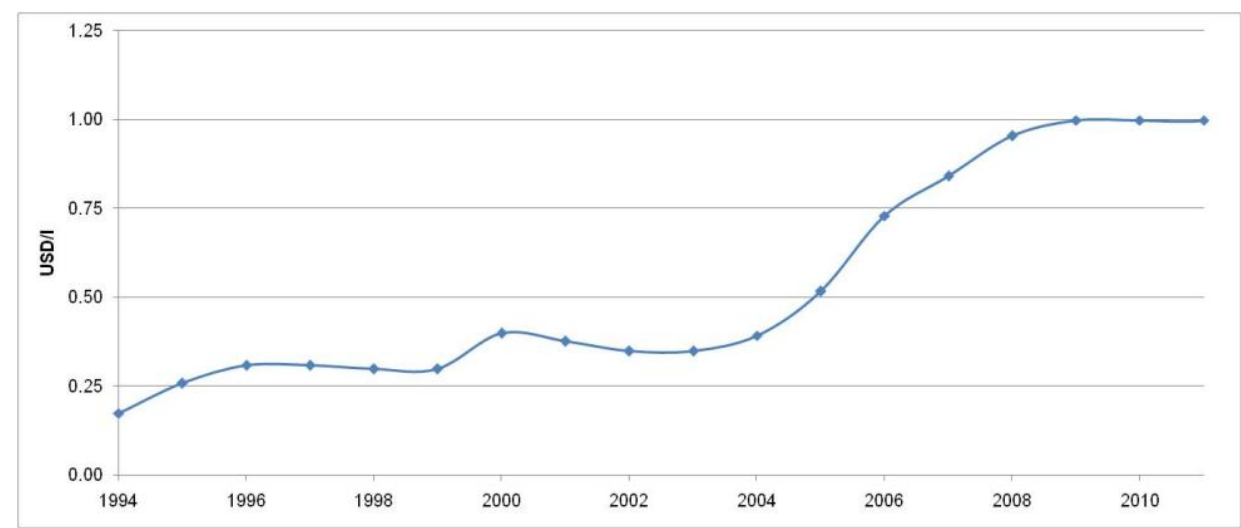

Figure 3: Trend of Diesel Price (NOC, 2010) 


\section{Emergence of Liquid Bio-fuel}

Jatropha curcas (Linnaeus) belongs to the family Euphorbiaceae and is thus closely related to other important cultivated plants like rubber tree and caster etc. This is interesting because it has certain virtues in common with them, which can be of significance for prophylactic plant protection [15]. It is believed to be a native of South America and Africa but later spread to other continents of the world by the Portuguese settlers [9]. Today it is found in almost all the tropical and sub-tropical regions of the world. There are more than 200 different names for its great significance to man and the various possibilities of its uses. When the botanist Carl Von Linne first classified the plants in 1753, gave it the botanical name "Jatropha curcas" from the Greek word "Jatros" meaning a "Doctor" and "trophe" meaning "nutrition". Even Linne had realized the potential of this plant for medicinal purposes [9].

Rudolph Diesel in 1878 introduced the work of Sadi Carnot, who theorized that an engine could achieve much higher efficiency than the steam engines of the day. Diesel sought to apply Carnot's theory to the internal combustion engine. Rudolph after inventing the diesel engine demonstrated it at the 1900 world exhibition in Paris, employing peanut oil and said; "The use of vegetable oils for engine fuels may seem insignificant today, but such oils may become in course of time as important as petroleum and the coal tar products of the present time" [14].

Since, the time of the invention of liquid bio-fuel, many experiments have been conducted on different types of engines. Different types of plant's species like Rubber seeds, Pongmia seeds, Rapeseeds, Jatropha seeds, Rice bran, Neem, Sal and other edible and non-edible oil bearing seeds have been used as a source of liquid bio-fuel [21]. The invention and research made thus from a long period have finally concluded that oil generated from vegetable species (bio-oil) and sugar containing agri- byproducts (ethanol) after transesterification for the former and fractional distillation to the latter, could be used as a combustion fuel in Engines and exhibited no such problems and even performed better by some measures than engines using diesel and petrol. The formulation of the liquid bio-fuel, what is now called biodiesel and fuel ethanol came out of those early experiments $[14,21]$.

\section{Fuel Properties of Jatropha Oil}

The oil content of Jatropha seed ranges between 35 to $40 \%$ (Gubitz, et al., 1999). The specific specific gravity of Jatropha oil is $0.9180(\mathrm{gr} / \mathrm{ml})$ compared to diesel oil $0.8410(\mathrm{gr} / \mathrm{ml})$ and the calorific value of the Jatropha oil is $41 \mathrm{MJ} / \mathrm{kg}$, whereas diesel oil has $45 \mathrm{MJ} / \mathrm{kg}$ [9]. Although the calorific value of Jatropha oil and petroleum diesel are fairly comparable, the use of pure Jatropha oil in unmodified diesel engines is generally not recommended because of higher viscosity and flash point of Jatropha oil can cause engine problems, including ignition failure and incomplete combustion $[3,13,18]$. Nonetheless, researchers have found that pure Jatropha oil that has been de-waxed and de-gummed (but has not been converted to biodiesel) can be run in unmodified diesel engines in blends of up to $20 \%$ percent Jatropha oil and $80 \%$ Petro-diesel [24]. The Jatropha oil content can be increased to as high as 50 percent if the fuel blend is preheated to reduce its viscosity [24]. At about 100 degrees celsius, the viscosity of Jatropha oil approaches that of petroleum diesel [3]. 


\section{Economics of Bio-Diesel Production in Nepal}

\subsection{Overall approach of the study}

Economics of biodiesel production discussed in this article is initiated with the estimation of area required for cultivating Jatropha curcas to meet the fuel substitution in the country. Input parameters for the cultivation are; plant density of 2500 plants per ha (raised with a layout of $2 \mathrm{~m} * 2 \mathrm{~m}$ plant spacing) [20, 9], productivity (yield) of the Jatropha considered is $5.5 \mathrm{~kg} / \mathrm{plant}$ as it has been found that yield ranges from 1-10 kg/plant) in different sources $[8,15]$. The analysis in this article is carried out with the yield of $5.5 \mathrm{~kg} / \mathrm{plant}$, whilst sensitivity of on the production cost of biodiesel is considered at varying yield of the plant. The oil content of Jatropha seed considered is $30 \%$ as it has been found in between 35 to $40 \%$ [9]. Rate of seedlings considered in the article is ( $0.043 \mathrm{USD} /$ plant), which is equivalent to NRs 3 per plant and has been varied by 3 units more not exceeding $0.101 \mathrm{USD} /$ seedling (i.e., NRs 9/seedling) while carrying the scenario evaluations. Regarding the suitability of blending proportion to estimate the cultivated area and further implications on the economy of producing biodiesel, estimates are based on blending proportion with Petro Diesel. The processing cost of biodiesel considered is equivalent to 0.6 USD per liter [22]

Table 1 indicates the input parameters for the economic evaluation of biodiesel production. Evaluation of the Lifecycle production cost is carried out in different scenarios as discussed in the following sections, where if not indicated the input parameters are used as presented in the Table 1.

Table 1: Input parameters for the cultivation

\begin{tabular}{|l|c|}
\hline Plants per ha & 2500 \\
\hline Yield (kg/tree) & 5.5 \\
\hline Oil content & $30 \%$ \\
\hline Plantation (plants/ha) & 2500 \\
\hline Seed Yield/ha & 13750 \\
\hline Re-plantation on the $2^{\text {nd }}$ year & $5 \%$ \\
\hline Collection Losses & $20 \%$ \\
\hline Rate of seedling & 0.043 \\
\hline Discount rate $(\%)$ & $10 \%$ \\
\hline
\end{tabular}

Three distinct scenarios are created to overview the influence on the cost of production, which are;

- Scenario-I: Lifecycle production cost at varying yields of Jatropha plant

- Scenario-II: Lifecycle production cost at varying prices of Jatropha seedlings

- Scenario-III: Lifecycle production cost at varying prices of raw oil seeds.

Evaluation of scenario is focused on to investigate the Levelised cost of producing biodiesel. The Levelised production cost (LPC) is calculated in order to provide a convenient summary 
measure of the overall competitiveness of different scenarios considered in the production of biodiesel. LPC represents the present value of the total cost of producing biodiesel (including cultivation and processing) over an assumed financial life and duty cycle (20 years in this article), converted to equal annual payments and expressed in terms of real price to remove the impact of inflation. It reflects overnight capital cost, fuel cost, fixed and variable O\&M cost, financing costs, and an assumed utilization rate for each technology [10] (EIA, 2010). Similarly, return on the investment (ROI) in different scenarios is also evaluated.

\subsection{Estimation of Land Required}

The estimated area required for different proportion of biodiesel blending increases at the equivalent rate of increase in the quantity of biodiesel required for blending. It is estimated that on top of the $10 \%$ blending, with every $5 \%$ increment on the blending proportion, area required for cultivation takes increases by a factor of 1.3. For the most likely blending of biodiesel (B20), considered in this article, the estimated area of the plantation is 34865 ha (Figure 4), which is $4 \%$ of the total available uncultivated land in the terrain and hilly belt of the country (i.e. 0.876 mil. ha) [11].

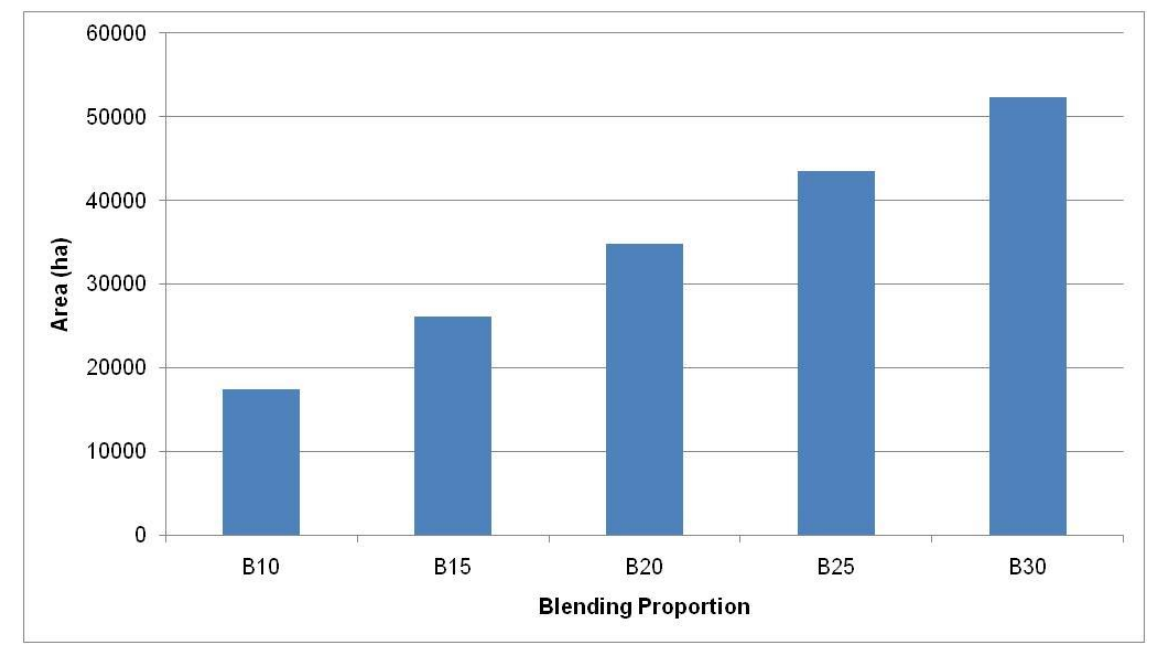

Figure 4: Potential area required for cultivation under the different requirement of blending

\subsection{Economic evaluation biodiesel production}

The estimated cost of cultivation is 1595 (USD/ha) (Table 2) In order to fulfill the requirement of $20 \%$ blending with Petro-diesel, estimated production of Jatropha seeds is 479 million tons from the area of 34865 ha with the yield of $5.5 \mathrm{~kg} / \mathrm{plant}$ (i.e. $13.75 \mathrm{tons} / \mathrm{ha}$ ). With the price of Jatropha seedling at $0.043 \mathrm{USD} / \mathrm{seedlings}$ (equivalent to $3 \mathrm{NRs} / \mathrm{seedling}$ ), the estimated investment required in the $1^{\text {st }}$ year of the plantation is 13.72 mil. USD, whereas for the second year and third year is 22.54 and 19.34 mil USD respectively. With these estimates the total production cost of Jatropha for generating oil seeds to substitute $20 \%$ of the diesel imported in 2011 is 55.59 mil. USD. The investment cost in the $2^{\text {nd }}$ year of plantation is high because it involves additional labor cost as $50 \%$ of yield is expected to be available from the $2^{\text {nd }}$ year and followed by $80 \%$ of the yield from $3^{\text {rd }}$ year and onward $[15,9,23]$. On the total cost of cultivation of the Jatropha, estimated shares of labor inputs is 79\%, fertilizer inputs (9\%), cost of 
seedlings including plant protection measures is $9 \%$ and irrigation input has a stake of $4 \%$. These entire shares are without considering the interest to the investment and without contingencies and returns from by-products.

Table 2: estimated cost of cultivation of Jatropha per ha

\begin{tabular}{|c|c|c|c|c|c|c|c|}
\hline \multirow{2}{*}{$\begin{array}{l}\mathrm{S} . \\
\mathrm{N}\end{array}$} & \multirow{2}{*}{ Particulars of Works } & \multirow{2}{*}{ Unit/ha } & \multirow{2}{*}{$\begin{array}{l}\text { Rate/ } \\
\text { Unit }\end{array}$} & \multicolumn{3}{|c|}{ Cost per annum (USD) } & \multirow{2}{*}{$\begin{array}{c}\text { Total. } \\
\text { (USD/ha) }\end{array}$} \\
\hline & & & & Year-I & Year-II & Year-III & \\
\hline 1 & Site preparation & MD & 8.972 & 8.97 & & & 8.97 \\
\hline 2 & Alignment, \& staking & MD & 8.972 & 8.97 & & & 8.97 \\
\hline 3 & $\begin{array}{l}\text { Digging of pits } 2500 \\
\text { numbers }\end{array}$ & MD & 62.801 & 62.80 & 6.28 & & 69.08 \\
\hline 4 & Cost of FYM @2 Kg/pit & Ton. & 35.887 & 35.89 & 3.59 & & 39.48 \\
\hline 5 & $\begin{array}{l}\text { Cost of fertilizer } \\
@ 250 \mathrm{gm} / \mathrm{plant}\end{array}$ & $\mathrm{Ha}$ & 14.355 & 14.35 & 14.35 & 14.35 & 43.06 \\
\hline 6 & $\begin{array}{l}\text { Mixing of FYM, } \\
\text { insecticides and refilling } \\
\text { pits at } 100 \mathrm{gm} \text {. per pit }\end{array}$ & $\mathrm{Ha}$ & 17.943 & 17.94 & 17.94 & & 35.89 \\
\hline 7 & $\begin{array}{l}\text { Cost of plants including } \\
\text { transport }\end{array}$ & Plants/ha & 0.043 & 107.02 & 5.35 & & 112.37 \\
\hline 8 & $\begin{array}{l}\text { Planting \& replanting } \\
@ 100 \text { plants per MD }\end{array}$ & $\mathrm{Ha}$ & 35.887 & 35.89 & 1.79 & & 37.68 \\
\hline 9 & Irrigation - 3 times & $\mathrm{Ha}$ & 26.915 & 26.91 & 26.91 & & 53.83 \\
\hline 10 & $\begin{array}{l}\text { Weeding, soil working, } \\
\text { application of fertilizer } \\
\text { etc. }\end{array}$ & На & 17.943 & 17.94 & 17.94 & & 35.89 \\
\hline 11 & $\begin{array}{l}\text { Plant protection } \\
\text { measures. }\end{array}$ & LS & 5.383 & 5.38 & 5.38 & 5.38 & 16.15 \\
\hline \multirow[t]{2}{*}{12} & $\begin{array}{l}\text { Collection (1 MD per } \\
100 \mathrm{~kg})\end{array}$ & $\mathrm{Ha}$ & 3.364 & 0.00 & 462.60 & 462.60 & 925.20 \\
\hline & Sub-total & & & 342.07 & 562.15 & 482.34 & 1386.56 \\
\hline \multirow[t]{2}{*}{13} & Interest & $10 \%$ & & 34.21 & 56.22 & 48.23 & 138.66 \\
\hline & Total & & & 376.28 & 618.37 & 530.57 & 1525.22 \\
\hline \multirow[t]{2}{*}{14} & Contingencies & $5 \%$ & & 17.10 & 28.11 & 24.12 & 69.33 \\
\hline & Grand total (USD/ha) & & & 393.38 & 646.48 & 554.69 & 1594.55 \\
\hline
\end{tabular}

Study estimates, based on $[8,15,20,12]$ 


\subsubsection{Scenario-I: varying Jatropha seed yield}

The Levelised cost of production is estimated considering the Lifecycle cost of the production of biodiesel for the period of 20 years. The estimated Levelised cost of cultivation is 0.019 (USD/plant) and 0.003 (USD/kg). With these costs of cultivation, the estimated Levelised cost of producing a unit liter of biodiesel is 0.759 (USD). The production cost of biodiesel in the two pilot biodiesel production plant of Nepal is found $0.68 \mathrm{USD} / \mathrm{l}$ (i.e. $61 \mathrm{NRs}$. /l) (Wegstein, et al., 2010). The estimated cost of producing biodiesel is found comparable with other countries. For e.g. The processing cost for producing a unit liter of biodiesel in India and Zimbabwe is 0.65 to 0.729 in 2000 (Openshaw, 2000), which is equivalent to 0.833-0.93 USD per liter considering the exchange rate of 2012. Similarly, the production cost of biodiesel with the productivity of Jatropha seeds (2.5-12 tonnes/ha) in Ghana in 2010 is 0.99 USD/liter [5].

Furthermore, as shown in Figure 5, the yield of the Jatropha plant $(\mathrm{kg} / \mathrm{plant})$ is one of the important parameters for generating biodiesel in an economically attractive manner. With the higher investment cost against the low productivity, it is expensive to produce biodiesel. With the yield of $1 \mathrm{~kg} / \mathrm{plant}$, the cost of cultivation is $0.03 \mathrm{USD} / \mathrm{plant}$, whereas with a yield of 5.5 $\mathrm{kg} / \mathrm{plant}$, the cost of cultivation is $0.019 \mathrm{USD} / \mathrm{plant}$. It reveals that with every $1.5 \mathrm{~kg}$ increment in the yield of a single plant, the cost of cultivation decreases at an average rate of $9 \%$ compared to yield of $1 \mathrm{~kg} /$ plant.

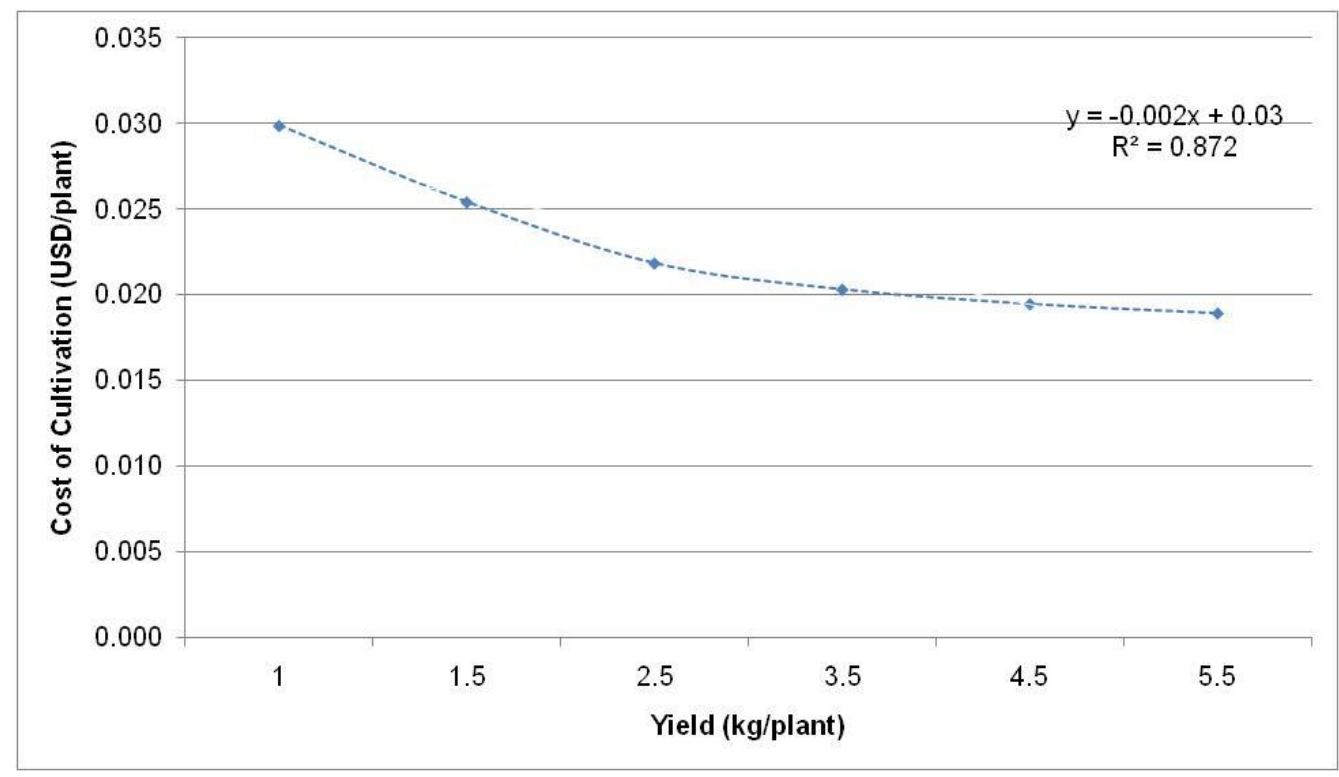

Figure 5: Cost of cultivation on varying yield of Jatropha plant

Similarly, with the similar variations on the yield of Jatropha plant, the production cost of Jatropha seeds (USD/kg) (Figure 6) shows that with every $1.5 \mathrm{~kg}$ per plant, the production cost per $\mathrm{kg}$ of Jatropha seeds decreases at an average rate of $34 \%$. With the yield of $5.5 \mathrm{~kg} / \mathrm{plant}$, the estimated cost of Jatropha seed is $0.003 \mathrm{USD} / \mathrm{kg}$. 


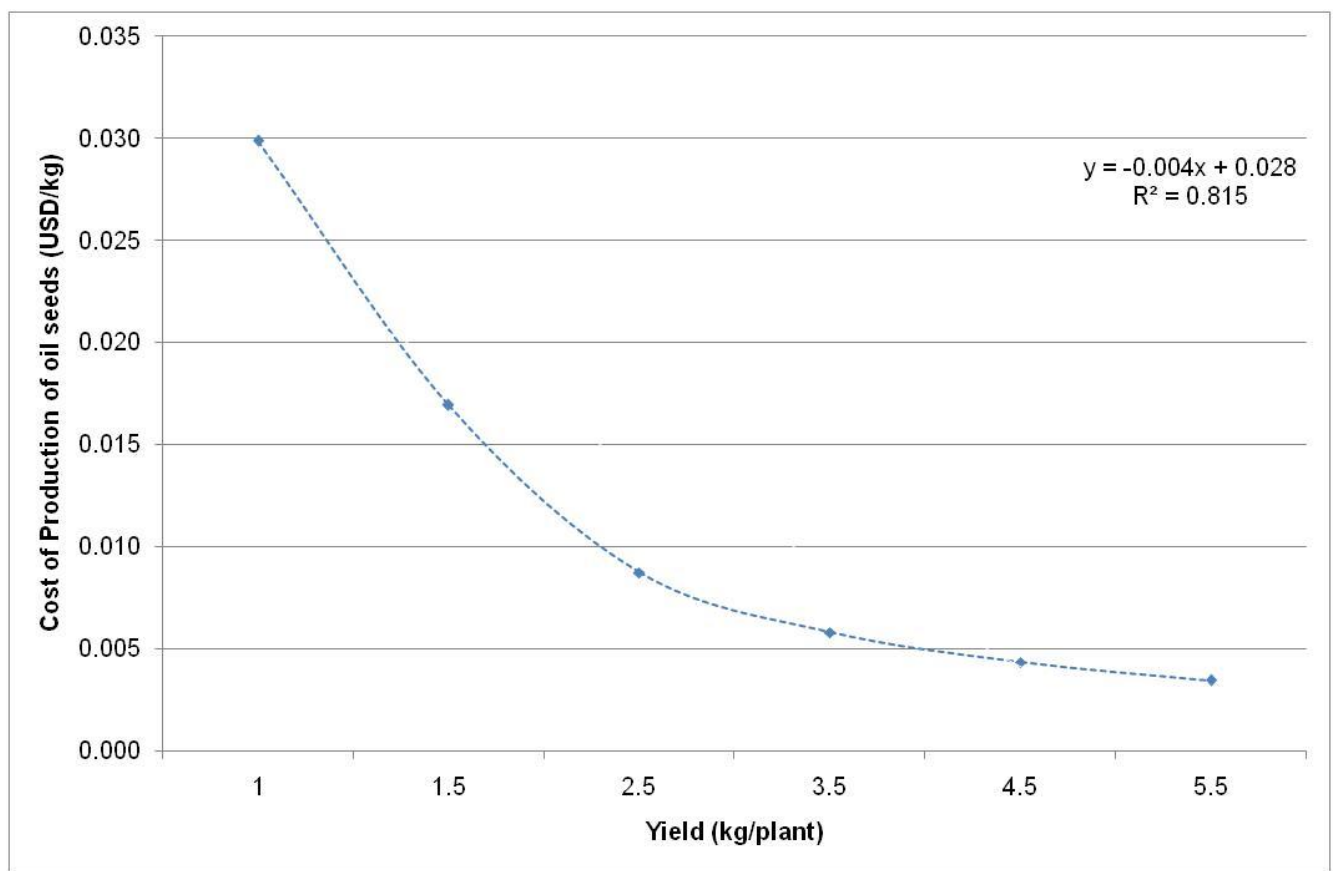

Figure 6: Cost oftoroduction of oil seeds on varying yield of Jatropha plant

Figure 7 indicates that the production cost of the biodiesel decreases at an average rate of $13 \%$, with every $1.5 \mathrm{~kg} / \mathrm{plant}$ increment in the yield of the Jatropha. The economics of biodiesel production hence shows that the yield of Jatropha if is less than $3.5 \mathrm{~kg} / \mathrm{plant}$, the cost of biodiesel is not competitive with the sales price of diesel available in the country (at 2011 price). The estimated cost of biodiesel in different yield rate is shown in Figure 7.

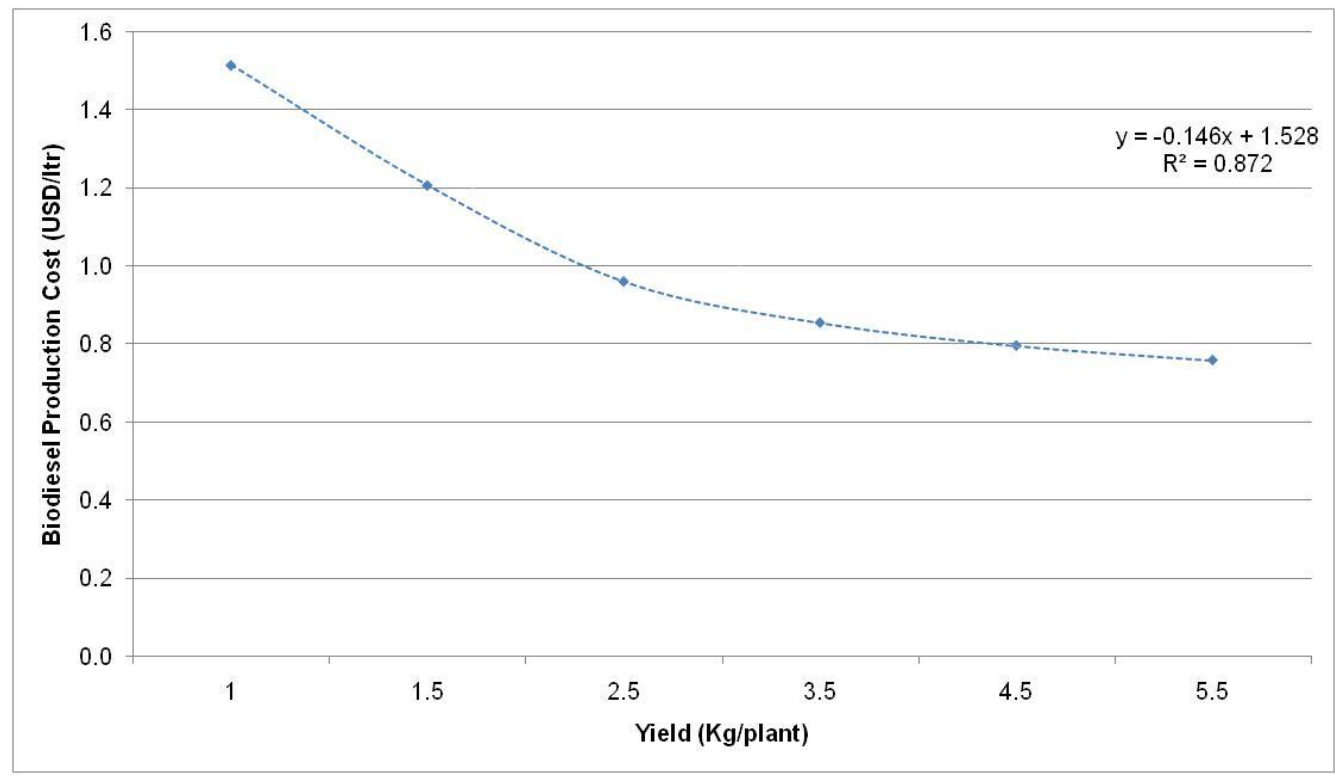

Figure 7: Cost of production of biodiesel on the varying yield of Jatropha plant 
The return on investment (ROI) is estimated considering the ratio of net present worth of the net gain from the investment to produce biodiesel and its consumption to the total investment for producing it. The net gain of from the production and consumption is estimated considering the difference of reduction on the expenses due to utilization of biodiesel in $20 \%$ blending proportion and expenses for utilizing biodiesel at the estimated production cost. The ROI on different yield rate of Jatropha plant (Table 3) indicates that the investment in the biodiesel production for fulfilling $20 \%$ blending on Petro-diesel will be attractive, if and only the yield of Jatropha plant is higher than $1 \mathrm{~kg} /$ plant.

Table 3: ROI at varying yield of Jatropha plant

\begin{tabular}{|l|c|c|c|c|c|c|}
\hline Yield (Kg/plant) & 1 & 1.5 & 2.5 & 3.5 & 4.5 & 5.5 \\
\hline ROI & 0.79 & 1.84 & 3.18 & 3.99 & 4.53 & 4.92 \\
\hline
\end{tabular}

\subsubsection{Scenario-II: at varying price of Jatropha seedlings}

Jatropha seedling is also one of the important parameters to produce biodiesel in a better economic way. In the Figure 8, the secondary ordinate indicates the cost of cultivation (per plant and $\mathrm{kg}$ ). With every 3 unit increment in the price of Jatropha seedling for plantation, the levelised cost of cultivation (per plant and $\mathrm{kg}$ ) and production of biodiesel (per liter) increases by $5 \%$.

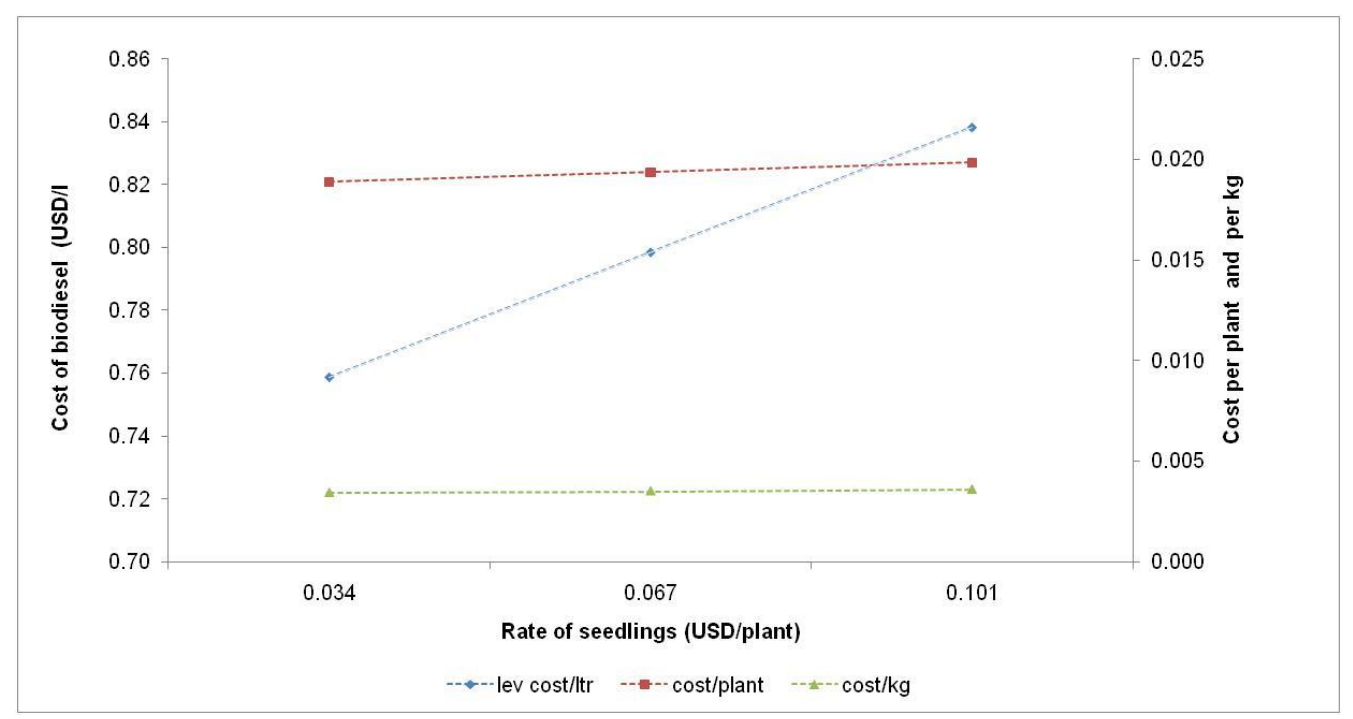

Figure 8: Production cost of biodiesel at varying rate of seedlings

Table 3, indicates that even tough investment in biodiesel production to satisfy $20 \%$ substitution of Petro-diesel is attractive at the given input parameters, the investment would be more attractive if the seedlings required for the plantation is available at lower prices. The ROI on the lowest price of seedlings considered in this article is 4.9 , whereas at the highest price it is 4.13 (Table 4). 
Table 4: RoI at varying price of seedlings

\begin{tabular}{|l|c|c|c|}
\hline $\begin{array}{l}\text { Price of seedlings } \\
\text { (USD/plant) }\end{array}$ & 0.034 & 0.067 & 0.101 \\
\hline ROI & 4.92 & 4.51 & 4.14 \\
\hline
\end{tabular}

\subsubsection{Scenario-III: at varying cost of raw oil seeds}

This scenario is created to investigate the influence of the cost of raw oil seeds, if the producers (processing entrepreneurs) have to buy to produce biodiesel. The Levelised cost of producing biodiesel is estimated considering with and without any cost of raw oil seeds. Figure 9 indicates that with every 5 unit increment in the cost of raw oil seeds, required for processing, the cost of biodiesel production will increase by an average factor of 1.27. The competitive price of biodiesel with the domestic sales price of Petro-diesel (of 2011) is possible if and only the price of raw oil seeds for processing is available at a price less than $0.28 \mathrm{USD} / \mathrm{kg}$.

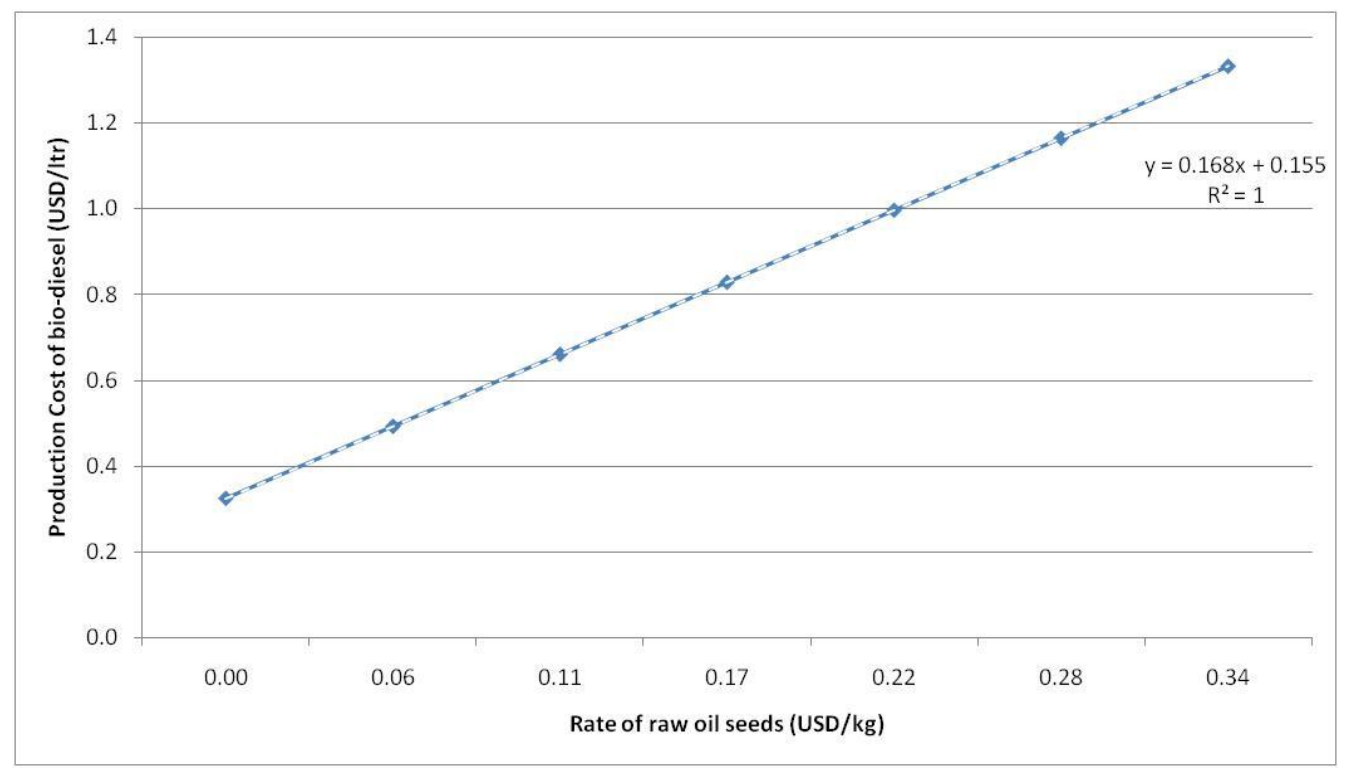

Figure 9: Production cost of biodiesel at varying rate of raw oil seeds.

\subsection{Socioeconomic Advantage}

As an economic benefit of fuel substitution in the country's economy, with the use of biodiesel as a local energy resource, it facilitates in the reduction in the national expenditure because of using imported Petro-diesel. Figure 10, indicates, the projected total cost incurred while consuming 100\% Petro-diesel, 20\% biodiesel and net gain due to a reduction of import shares of the projected fuel consumption. It is estimated that for the period of 20 years and considering the inflation on the Petro-diesel's sales price (at 9.15\%), the net present worth of the gain from the investment is 4056 mil. USD.

Furthermore, [12] has indicated that on an average 150 man-days per ha per annum is the potential employment generation from the investment in biodiesel production. This result of 
potential employment generation of 5.29 million people from 34865 ha of cultivation area, while producing bio-diesel to substitute $20 \%$ of the sales of Petro-diesel in 2011.

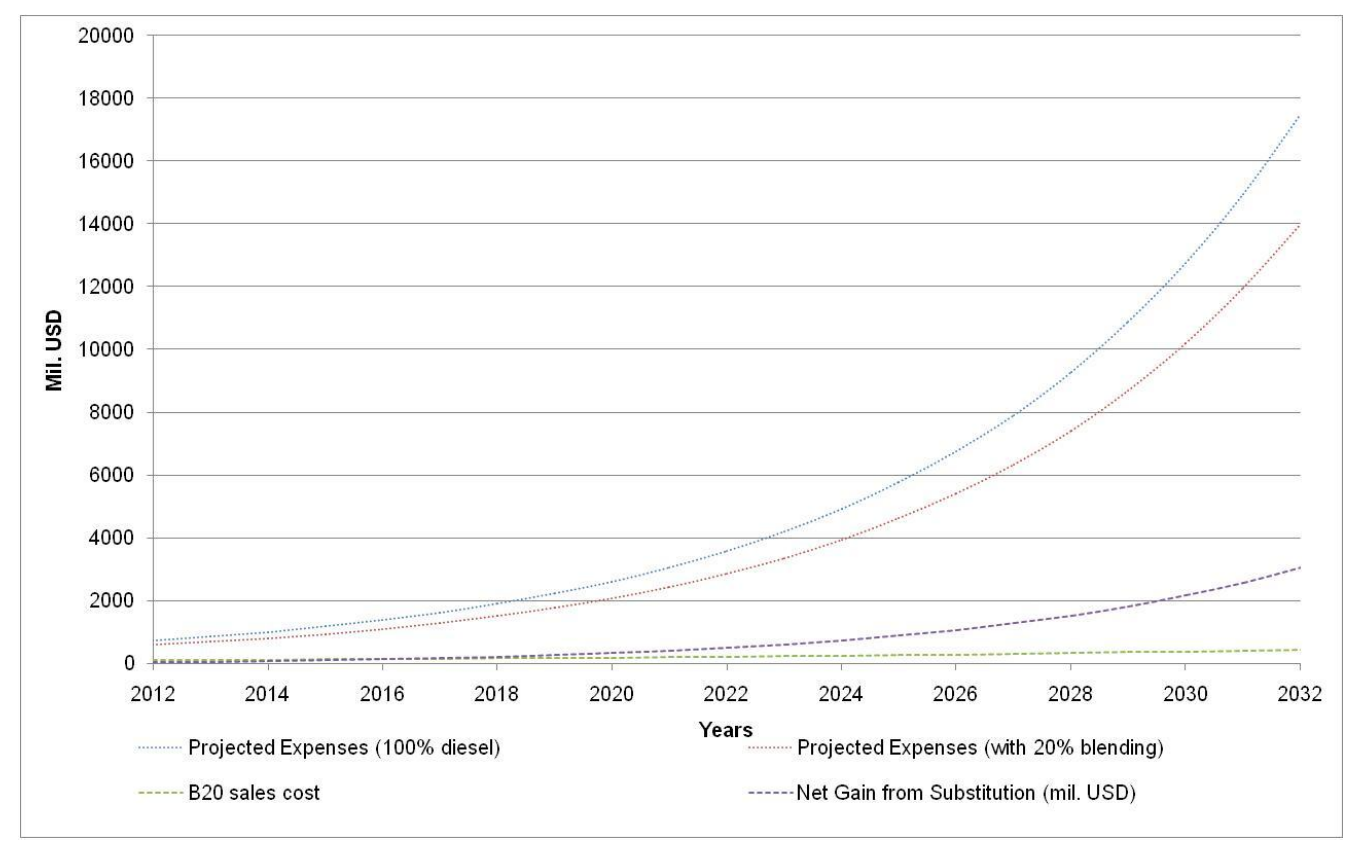

Figure 10: Project fuel expenses with and without biodiesel blending

\section{Conclusion}

There is no doubt the fossil fuel reserve is depleting day by day and it is necessary to think about the alternative fuel. Nepal is heavily dependent on the fossil fuel; the escalating price is one of the greatest problems for Nepalese economy. Considering aspects like climate change, fossil fuel reserve depletion, fuel politics and for economic enhancement, Nepal needs to enter into the age of bio-fuel.

It is obvious to say and ask a question that "Do the country have the proper base to enter into liquid bio-fuel to substitute fossil fuel (Petro-diesel)?" But until and unless the first step is not taken this kind of question will always rise. The only solution is; now it's the time to make complete awareness of the technology, start nurseries, train local farmers for cultivation, collection, processing and marketing of bio-fuel resources. Bio-diesel consumption can be started from the local level like agricultural application (operation of irrigation pumps and agroprocessing equipments), the transportation sector and decentralized power production can be facilitated.

Analysis carried out in this article reveals that it is very much feasible to substitute Petro-diesel with biodiesel, where blending proportion (B20) seems attractive at different scenarios of yield of Jatropha plant, price of seedling and price of raw oil seeds. Since, the country, currently do not have an immediate resource to substitute $20 \%$ diesel, formulation of fossil fuel dependency reduction strategy should be outlined by the government of Nepal and should be able to delineate the gradual substitution of Petro-diesel in the future. This will create a basis to initiate the commercial cultivation of the Jatropha to fulfill the future energy requirement of the country. In addition to this, the strategy of biodiesel production and consumption in the country should 
also consider the development of a strong legislation and policy that also covers issues of food security. Proper monitoring mechanism should be developed to ensure that agricultural land is not used for this purpose. As identified in the analysis of this article, for $20 \%$ blending, $4 \%$ of the uncultivated land of the country (representing terrain and hill only) are enough. A long term bio-fuel promotion, fuel substitution policy should be developed by the government so that resource generation can be carried out accordingly. Further research and development of liquid bio-fuel technologies to identify prospects of its application would be supporting tool to reduce the fossil fuel dependency in the country.

\section{References}

[1] AEPC.a. (2011). Biofuel Program. Existing Programs under National Bio-fuel Program in FY 2068/069, accessed on $0607,2012$.

[2] AEPC.b. (2011). Biodiesel Quality Control Laboratory . Biofuel Program. http://www.aepc.gov.np/index.php?option=com_content\&view=article\&id=174\&Itemid=190, accessed on $0607,2012$.

[3] Agarwal, D., and Agarwal, A. K. (2007). Performance and emissions characteristics of Jatropha oil (preheated and blends) in a direct injection compression ignition engine. Applied Thermal Engineering, 27, 2314-2323.

[4] Chalise, K. (2011). Fuel import burns Nepal's total export. The Himalayan Times. 06 23, 2011.

[5] Cynthia, O. B., and Teong, L. K. (2011). Feasibility of Jatropha oil for biodiesel: Economic Analysis. Linköping : World Renewable Energy Congress 2011, Sweden, Bioenergy Technology (BE).

[6] EIA. (2011). Levelized Cost of New Generation Resources in the Annual Energy Outlook 2011http://205.254.135.24/oiaf/aeo/electricity_generation.html, accessed on 05 06, 2012.

[7] Forson, F. K, Oduro, E. K., and Donkoh, E. H. (2004). Technical note Performance of Jatropha oil blends in a diesel engine. Renewable Energy, 29, 1135-1145.

[8] Goswami, A. (2006). Long-run marginal-cost based economic evaluation of biodiesel production fro Jatropha, Biofuel TERI. 5-25.

[9] Gubitz, G.M, Mittelbach, M and Trabi, M. (1999). Exploitation of the tropical oil seed plant Jatropha curcas L., Bioresource Technology, 67, 73-82.

[10] IEA. (2009). Selected 2009 Indicators for Nepal. International Energy Agency. http://www.iea.org/stats/indicators.asp?COUNTRY_CODE=NP, accessed on 3 11, 2012.

[11] ISRC. (2008). Village Development Committee Profile of Nepal, A Socio-Economic Development Database of Nepal. Intensive Study \& Research Centre (ISRC). 1-150.

[12] Jain, S. K., Kumar, S. and Chaube, A. (2011). Jatropha biodiesel: Key to attainment of sustainable rural bioenergy regime in India. Scholars Research Library , Archives of Applied Science Research, 3 (1), 425 435.

[13] Kandpal, J. B., and Madan, M. (1995). Jatropha curcus: a renewable source of energy for meeting future energy needs. Renewable Energy, 6, 159-160.

[14] Krawczyk, T. (1996). Biodiesel - alternative fuel makes inroads but hurdle remains. Int. News Fats, Oils Related Mater. -INFORM, 801-815.

[15] Lele, S. (2006). India's Bio-diesel Scene: The Latest Biodiesel Developments In A Nation Determined To Achieve Energy Independence "Ethanol Blending To Reduce Emissions from Heavy-Duty Diesel Engines. 1-15. www.ornl.gov/sci/eeree/PDFs/sci_tech_hilights/No_1_2001p9.pdf, accessed on 0104 2012. 
[16] NAEF (2011). Renewable Energy: Biodiesel. http://www.naef-nepal.org/, accessed on 06 07, 2012.

[17] NOC (2010). Import and Sales of Petroleum Products in Nepal. Nepal Oil Corporation, Government of Nepal. 1-15.

[18] Openshaw, K. (2000). A review of Jatropha curcas: an oil plant of unfulfilled promise Biomass and Bioenergy. 19.1-15.

[19] Pramanik, K. (2003). Properties and Use of Jatropha Curcas Oil and Diesel Fuel Blends in Compression Ignition Engine, Renewable Energy, 38, 239-248.

[20] Radich ? (2004). A Biodiesel Performance Cost and Use, Energy Information Administration. http://www.eia.doe.gov/oiaf/analysispaper/biodiesel/index.html, accessed on - 4 5, 2008.

[21] Ramadhas, A.S., Jayaraj, S., and Muraleedharan, C. (2005). Technical note Characterization and effect of using rubber seed oil as fuel in the compression ignition engines. Renewable Energy, Department of Mechanical Engineering, National Institute of Technology, Calicut, 795-803.

[22] Ramesh, D., Sampathrajan, A., and Venkatachalam, P. Production of biodiesel from Jatropha crucas oil by using pilot biodiesel plant, Agriculture Engineering College and Research Institute, Tamil Nadu Agriculture University, India, 1-6.

[23] Sharma, B., and Banskota, K. (2006). Prospects of Liquid Biofuel in Nepal, CES, ICIMOD.

[24] Singh, R.N., et al. (2008). SPRERI experience on holistic approach to utilize all parts of Jatropha curcas fruit for energy, Renewable Energy. 33, 1868-1873.

[25] WECS (2010). Energy Synopsis Report [Report], Kathmandu : Government of Nepal, Ministry of Energy, Water and Energy Commission, 1-30.

[26] Wegstein, M., and Adhikari, N. (2010). Financial Analysis of Jatropha Plantations, Journal of the Institute of Engineering, Kathmandu, 8(1), 1-5. 